Sci. Journal Impact

Factor: $6.1(2018)$

ICV: 90.90 (2018)

(c) (i) (3)

Copyright@IJCRR

\section{$\nabla$ \\ IJCRR \\ Section: Healthcare \\ Pre-Conception and Pre-Natal Diagnostic Techniques Act: Knowledge and Attitude of Students of Commerce College in Rajasthan}

\author{
Anand Ranjan'1, Dilip Kumar L'ㄹ, Pradeep P. Shinde
}

'Assistant Professor, Department of Community Medicine, PIMS Udaipur, Rajasthan, lndia; ${ }^{2}$ Associate Professor, Department of Community Medicine, PIMS Udaipur, Rajasthan, India; 3Professor, Department of Community Medicine, PIMS Udaipur, Rajasthan, India.

\title{
ABSTRACT
}

Background: The Pre-Conception and Pre-Natal Diagnostic Techniques (PCPNDT) Act was first enforced in 1994 and then updated 2003 to control an age-old and insistent social problem of female foeticide in India.

Aims and Objective: To assess the awareness regarding the PCPNDT Act and sex ratio, among the college's students and to sensitize the students regarding declining sex ratio and create awareness by education.

Materials and Methods: A cross-sectional opinion study was carried out in the commerce college students of Udaipur under the jurisdiction of the urban health centre area of Pacific Medical College and Research Center. Total of 336 respondents participated with good response. Pre-tested and predesigned proforma was used to collect information under the supervision and analyzed and interpreted using statistical tools. The sensitization was done with lecture and question-answer session.

Results: Majority (85.11\%) were found in the age bracket of 20 to 22 years with more female respondents. Almost (91.48\%) aware of the adverse sex ratio and the PCPNDT Act. The commonest source of information was mass media (82.73\%) more than half $(58.92 \%)$ were aware that sex determination is not permitted legally. Among them (27.97\%) exactly knew the punishment profile for violators. Unavailability of brides to marry and rise in violence against women remained common future implication of female foeticide. Girls attitude towards not going for sex determination found statistically significant compared to boys. The commonplace of Male/Female discrimination for girls was outside home and institute while for boys it was in the institute.

Conclusion: Although, the majority were aware of the adverse sex ratio and PCPNDT Act, knowledge about exact punishment for violators seemed to be less. Boys attitude towards not going for sex determination in future was less compared with girls. Proper guidance sessions are urged for them.

Key Words: PCPNDT act, Sex ratio, Awareness, Female foeticide

\section{INTRODUCTION}

Since antiquity, we Indian are experiencing a long history of social evils and traditions.

The widespread social evils till the first half of the $20^{\text {th }}$ century were the Sati system, female infanticide, child marriage, caste system, devadasi, purdah system, and untouchability. About these very less is known to the people.

A female infanticide is an act of murdering a female infant deliberately Female infanticide and its practice were widely common in Indian families and communities of colonial India, irrespective of class and caste. Sex-selective abortion was also commonly adapted by many families. This resulted in and a significant decline in the number of girl child in
India over the years. ${ }^{1}$ Sociability ratings for male and female is also likely to differ quite significantly many factors often affect sociability ratings among the youths, in general, some include youth age brackets, family, religious disposition, education, gender and cultural values. ${ }^{2}$

The census 2001 reported alarming sharp fall of sex ratio of children (0-6 year) from 962 (1981), 945 (1991) to 927 in 2001. In 2011 this goes worse and reach down to 914 per 1000 males. Categorical worst performing states are Haryana (830), Punjab (846), Delhi and Chandigarh (867), Rajasthan (883) and Gujarat (886). Government of India enacted legislation in 1994, entitled Pre-Conception and Pre-Natal Diagnostic Techniques (PCPNDT) act to regulates and prevent misuse of technologies for sex determination.

\section{Corresponding Author:}

Dr. Dilip Kumar L, Associate Professor, Department of Community Medicine, PIMS Udaipur, Rajasthan, India. Email: dilippareek27@gmail.com

ISSN: 2231-2196 (Print)

Received: 14.07.2020
ISSN: $0975-5241$ (Online)

Revised: 27.08 .2020
Accepted: 04.10 .2020
Published: 27.10 .2020 
The act was implemented in 1996 and was amended in 2003 to Preconception and Prenatal Diagnostic techniques. This act provides the prohibition of sex selection before and after conception. As on September 30, 2009, 36477 bodies registered using ultrasound in the country and 431 machines closed with 603 ongoing cases in the court of law. ${ }^{3}$ Sex ratio is defined as the number of Female per thousand males. ${ }^{4} \mathrm{Fe}-$ male foeticide is perhaps one of the worst forms of violence against women, where women are denied for most basic \& fundamental right i.e. "the right to life" 5 .

\section{MATERIALS AND METHODS}

The present cross-sectional institution-based opinion study was carried out in commerce college of Udaipur under the jurisdiction of the Urban health centre of Pacific Institute of Medical Sciences and Research Centers. Informed written consent was obtained from the Head of the institute and the purpose of the study was explained to him. With the help of teachers from the same institute, a pretested and predesigned proforma was given to all the students with verbal permission from them. Those who were willing and present on the day of the visit were included in the study. In total 336 respondents participated with good response. In presence of investigators and teachers, participants fill the perform as without permitting to discuss with each other. After filling of proforma, a lecture was delivered on the same to resolve the queries if any. Strict confidentiality was maintained about the collected data and Interpreted and analyzed using appropriate statistical techniques.

\section{RESULTS}

\section{Demographic representations}

In the present study, the majority of the students belonged in the age bracket of 20 to 22 years.

Female were more in number than male respondents.

Table 1: Age and sex-wise distribution of respondents

\begin{tabular}{lccc} 
Age & Male $(\%)$ & Female $(\%)$ & Total $(\%)$ \\
18 & $14(10.14)$ & $12(6.06)$ & $26(7.73)$ \\
20 & $16(11.59)$ & $62(31.31)$ & $78(23.21)$ \\
22 & $60(43.47)$ & $86(30.30)$ & $146(43.45)$ \\
24 & $34(24.63)$ & $28(14.14)$ & $62(18.45)$ \\
26 & $14(10.14)$ & $10(5.05)$ & $24(7.14)$ \\
Total & $138(41.08)$ & $198(58.92)$ & 336 \\
\hline
\end{tabular}

Awareness about gender ratio and PCPNDT act

Almost many respondents were aware of the adverse gender ratio and the PCPNDT Act. The difference in awareness in boys and girls was not statistically significant.
Table 2: Distribution of respondents according to awareness of gender ratio and PCPNDT Act

\begin{tabular}{lccc} 
Awareness & Boys (\%) & Girls (\%) & Total (\%) \\
Yes & $128(92.75)$ & $176(88.89)$ & $304(91.48)$ \\
No & $10(7.25)$ & $22(11.11)$ & $23(9.52)$ \\
Total & 138 & 198 & 336 \\
\hline
\end{tabular}

\section{Source of information about the act}

Majority of participants voted mass media and internet as their primary sources of information. None of the participants replied that doctors or physicians are their sources of information. Very few agree that family or friends are their sources of information and most were unable to answer.

\section{Table 3: Source of information about the PCPNDT} Act.

\begin{tabular}{lc} 
Source & Number $(\%)$ \\
Family members and friends & $26(7.73)$ \\
Teachers & $4(1.19)$ \\
Doctors & o (oo.oo) \\
Media \& Internet & $278(82.73)$ \\
Not answered & $48(14.28)$ \\
\hline
\end{tabular}

\section{Awareness about legal permission of gender detection}

About $58.92 \%$ of respondents were aware that, prenatal sex determination is not legally permitted. Girls (63.63\%) were more aware compared with boys $(52.17 \%)$. Many participants answered that they do not this acts and whether there is a provision of legal permission to do gender detection.

Table 4: Distribution of respondents as per awareness about legal permission of Sex detection.

\begin{tabular}{lccc} 
Awareness & Boys (\%) & Girls (\%) & Total (\%) \\
Yes & $16(11.59)$ & $28(14.14)$ & $44(13.09)$ \\
No & $72(52.17)$ & $126(63.63)$ & $198(58.92)$ \\
Do not Know & $50(36.23)$ & $44(22.22)$ & $94(27.98)$ \\
Total & 138 & 198 & 336 \\
\hline
\end{tabular}

\section{Awareness about punishment under PCPNDT}

Act

There are different provisions of punishments under this act for doing illegal prenatal gender detection. This includes monetary fine, imprisonments or both, suspend or dispend form the job if a person is employed somewhere. Only $1 / 3^{\text {rd }}(27.97 \%)$ was exactly aware of punishment under the PCPNDT Act. Girls were more aware compared with boys (2.61:1). 
Table 5: Awareness about the type of punishment under the PCPNDT Act

\begin{tabular}{lccc} 
Punishment & Boys (\%) & Girls (\%) & Total (\%) \\
Fine & $24(17.39)$ & $26(13.13)$ & $50(14.88)$ \\
Imprisonment & $10(7.24)$ & $22(11.11)$ & $32(9.52)$ \\
Fine + Imprisonment & $26(18.84)$ & $68(34.34)$ & $94(27.97)$ \\
Removal from job & $64(46.37)$ & $28(14.14)$ & $92(27.38)$ \\
Do not Know & $14(10.14)$ & $44(22.22)$ & $58(17.26)$ \\
Total & 138 & 198 & 336 \\
\hline
\end{tabular}

Opinion on the future consequences

Many participants $(80.95 \%)$ felt that there will be an increase in crime against women followed by, a smaller number of girls to marry for boys $(77.97 \%)$. About $57.14 \%$ felt that no mothers and sisters will be there in future. Few also responded that this may cause an adverse effect on female health because of repeated pregnancies and forced abortions. Possibility of inter-caste marriages, polyandry were also answered by many participants.

Table 6: Impact of Female Foeticide on society

\begin{tabular}{lc} 
Effects of Female Foeticide & Number (\%) \\
$\begin{array}{l}\text { No girls for the Boys to marry. } \\
\begin{array}{l}\text { Increase in sexual and social crime against } \\
\text { women. }\end{array}\end{array}$ & $262(77.97)$ \\
$\begin{array}{l}\text { No mothers and sisters in future. } \\
\begin{array}{l}\text { Adverse effect on female health because of } \\
\text { repeated }\end{array}\end{array}$ & $192(57.14)$ \\
pregnancies \& forced abortions & $84(25)$ \\
$\begin{array}{l}\text { Any other (Inter-caste marriages, polyan- } \\
\text { dry, etc.) }\end{array}$ & $12(3.57)$ \\
\begin{tabular}{l} 
Do not know exactly \\
\hline
\end{tabular} & $46(13.69)$ \\
\hline
\end{tabular}

\section{Personal views prenatal gender detection}

About $2 / 3^{\text {rd }}$ of the participants $(69.05 \%)$ had a positive attitude towards not doing sex determination in future. Girls outnumbered the boys, found to be statistically highly significant.

Table 7: Differences of views on prenatal gender determination

\begin{tabular}{lccc}
$\begin{array}{l}\text { Prenatal Sex } \\
\text { determination in } \\
\text { future }\end{array}$ & Boys (\%) & Girls (\%) & Total (\%) \\
Yes & $41(30.45)$ & $12(6.06)$ & $54(16.07)$ \\
No & $68(49.27)$ & $164(82.82)$ & $222(69.05)$ \\
Cannot say & $28(20.28)$ & $22(11.12)$ & $50(14.88)$ \\
Total & 138 & 198 & 336 \\
\hline
\end{tabular}

In life encounter with gender discrimination

About $59.59 \%$ girls \& $75.36 \%$ boys never encountered male/female discrimination in life. The commonest place for discrimination for girls was outside home and institute i.e. $40.59 \%$ while boys the place was institute i.e. $14.49 \%$.

Table 8: Distribution of respondents ever encountered Male/Female discrimination at various places

\begin{tabular}{lll} 
Discrimination & Boys(\%) & Girls(\%) \\
At Home & $4(2.89)$ & $28(14.14)$ \\
At Institute & $20(14.49)$ & $36(18.18)$ \\
In other Surroundings & $10(7.25)$ & $82(40.59)$ \\
No & $104(75.36)$ & $118(59.59)$ \\
\hline
\end{tabular}

\section{DISCUSSION}

In the present study, Commerce undergraduates participated with the preponderance of female students agreed regarding adverse sex ratio and female foeticide $(91.48 \%)$. These findings are comparable with the previous study. ${ }^{6}$ Different cross-sectional studies reported $98 \%$ of awareness on medical students in Mumbai and 58\% among the general population. ${ }^{7,8}$ Mass media and the Internet remained the commonest source of information regarding PCPNDT Act awareness.

Previously similar results were reported wherein, 90\% agreed and vote to media as a source of knowledge. ${ }^{7,8}$ Majority of participants voted mass media and internet as their primary sources of information. None of the participants replied that doctors or physicians are their sources of information. Very few agree that family or friends are their sources of information and most were unable to answer.

In our study, about $58.92 \%$ were aware that female foeticide determination is not legally permitted. Many participants answered that they do not this acts and whether there is a provision of legal permission to do gender detection. This percentage of the respondent is less as compared to the previous report who states that $79 \%$ of adolescent girls were aware of it. Only one third $(27.97 \%)$ students were aware of the correct punishment scenario in PNDT Act, which is the more compared previous study by Murarkar and team who reported $18.33 \%$ among adolescent girls ${ }^{7}$ but less compared with the study by Metri and team who reported $53 \%$ among teachers of Hassan district Karnataka. ${ }^{8}$ There are different provisions of punishments under this act for doing illegal prenatal gender detection. This includes monetary fine, imprisonments or both, suspend or dispend form the job if a person is employed somewhere. Girls were more aware compared with boys (2.61:1).

The present study focused increase in sexual and social crime against women as an impact of female foeticide in future $(80.95 \%)$ followed by a smaller number of girls to marry 
(77.97\%).

Half of the participants also answered that there will be no mothers and sisters in future. Few also responded that this may cause an adverse effect on female health because of repeated pregnancies and forced abortions. Possibility of inter-caste marriages, polyandry was also answered by many participants. Our findings are comparable to study by Dadwani and team who compare the urban and rural population and reported that $76.5 \%$ answered the lack of bride in future from urbanities and $73.9 \%$ from rural people. ${ }^{6}$ Further $43 \%$ response to the increase in sexual and social crime is also reported. ${ }^{4}$ Commonest place of discrimination for girls was outside home and institute while for boys institute.

\section{CONCLUSION}

The study shows that most of the student are aware of sex determination and female foeticide and voted mass media and the Internet as a primary source of information. More than half were aware that sex determination is illegal and few were aware of the punishment modalities for defaulters. Crime against women may increase in future and there will be no girls to marry are the future demerits of not this social evil. We conclude that the knowledge and attitude regarding PCPNDT act need to reach to maximum sections of the community the provisions have to be implemented compulsorily.

\section{ACKNOWLEDGMENT}

Authors acknowledge the immense help received from the scholars whose articles are cited and included in references to this manuscript. The authors are also grateful to authors / editors / publishers of all those articles, journals, and books from which the literature for this article has been reviewed and discussed.

\section{Conflict of Interest: Nil}

Source of Funding: Nil

\section{REFERENCES}

1. Basumatary A. The study of the institution of female infanticide in colonial India. J IntAcad Res Multidiscipl2015;3(7):26-33.

2. Baraskar VJ, Shinde PP. To study the gender difference in personality factor and anxiety in adolescents-sociality self-confidence ambition and Anxiety. J Evidence-Based Med Healthcare2018;5(18):123-129.

3. Yadav KJ, Ganapa P, Fernandes J et al. Awareness and perception regarding female foeticide among adolescents in the rural community of Nalgonda district, Telangana. IntJ Comm Med Pub Health2018;5(7):3106-3110.

4. Patil P, Singh V, Chavan S. Knowledge and attitude regarding PCPNDT Actamong medical undergraduate. Innovative J Medical Health Science2014;4(2):83-85.

5. Siddhu TK, Kumar S, Paramjit E, Kaur S. A study of knowledge and attitude regarding the PCPNDT Act among medical undergraduate regarding prenatal sex determination \& female foeticide. Int J Med Commu Health2011;13(3):410-417.

6. Dadwani RS, Thomas T. Knowledge regarding sex ratio \& PCPNDT Act: Across sectional study. Int J Sci Res2014;3(8)274276.

7. Murarkar SK, Ghate MM, Joshi AM. A study of knowledge and attitude of adolescent girls in the rural area regarding prenatal sex determination and female foeticide. Ind J Mater Child Health2013;15(4):2-7.

8. Metri SS, Venktesh GM, Thejeseari HL. Awareness regarding Gender preferences female foeticide among the teachers in Hassan District, South India. J Clin Diag Res 2011;5(7):1430-1433. 